\title{
1 Different temporal trends in vascular plant and bryophytes 2 communities along elevational gradients over four decades of 3 warming
}

4 Antoine Becker-Scarpitta*1,2, Diane Auberson-Lavoie ${ }^{1}$, Mark Vellend ${ }^{1}$

5 1: Département de Biologie, Faculté des Sciences, Université de Sherbrooke, Sherbrooke, Québec, $6 \quad$ Canada.

7 2: Spatial Foodweb Ecology Group, Faculty of Agriculture and Forestry, Department of Agricultural Sciences, University of Helsinki, Helsinki, Finland

9 Contact: *Corresponding author: Antoine Becker-Scarpitta, Spatial Foodweb Ecology Group,

10 Faculty of Agriculture and Forestry, Department of Agricultural Sciences, University of Helsinki,

11 Helsinki, Finland. antoine.becker.scarpitta@gmail.com

\section{$12 \underline{\text { ORCID }}$}

13 Antoine Becker-Scarpitta: 0000-0001-9241-091X

\section{Database}

15 Data are stored in forestREplot database (http://www.forestreplot.ugent.be/) under the code:

16 N_AM_005 for Mont-Mégantic and N_AM_008 for Forillon. All plant specimens identified at the

17 species level were deposited in the Marie-Victorin herbarium (Université de Montréal, Canada.)

18 and all locations were entered into the GBIF database (GBIF - https://www.gbif.org/).

\section{$19 \underline{\text { Abstract }}$}

20 1: Despite many studies showing biodiversity responses to warming, the generality of such

21 responses across taxa remains unclear. Very few studies have tested for evidence of bryophyte 
22 community responses to warming, despite the fact that bryophytes are major contributors to

23 diversity in many ecosystems, playing a central role in ecosystem functions. Understanding

24 variation among taxa in their responses to warming is crucial for identifying priorities in

25 conservation.

26 2: We report an empirical study comparing long-term change of bryophyte and vascular plant

27 communities in two sites with contrasting long-term warming trends. To assess long-term

28 responses of ecological communities to warming, we used "legacy" botanical records as a baseline

29 for comparison with contemporary resurveys.

30 We hypothesized that ecological changes would be greater in sites with a stronger warming trends,

31 and that vascular plant communities would be more sensitive than bryophyte communities to

32 climate warming. For each taxon in each site, we quantified the magnitude of changes in species'

33 distributions along the elevation gradient, species richness, and community composition.

34 3: Temporal changes in vascular plant communities were consistent with the warming hypothesis,

35 but this was not the case for bryophytes. We also did not find clear support for the hypothesis that

36 vascular plants would show greater sensitivity than bryophytes to warming, with results

37 depending on the metric of community change. As predicted for sites with a strong warming trend,

38 we found a significant upward shift in the distributions of vascular plants but not bryophytes.

39 Synthesis: Our results are in accordance with recent literature showing that local diversity can

40 remain unchanged despite strong changes in composition. Regardless of whether one taxon is

41 systematically more or less sensitive to environmental change than another, our results suggest

42 that vascular plants cannot be used as a surrogate for bryophytes in terms of predicting the nature

43 and magnitude of responses to warming. In sites that experienced the same environmental 
45 in the same ways. Thus, to assess overall biodiversity responses to global change, data from

46 different taxonomical groups and community properties need to be synthesized.

\section{$47 \quad \underline{\text { Key words }}$}

48 Plant population and community dynamics, Global change ecology, vascular plant, bryophyte,

49 warming, elevational gradient, historical ecology, legacy data, biodiversity, forest, understory

50 vegetation, resurvey, temporal dynamic,

\section{Introduction}

52 Ecological impacts of global changes on biodiversity can take many different forms (McGill,

53 Dornelas, Gotelli, \& Magurran, 2015; Vellend, Baeten, et al., 2017). In the context of climate

54 warming, montane ecosystems have received considerable attention due to clear predictions of

55 changes in species' distributions (upslope shifts) and community composition (favouring warm-

56 adapted species) along elevation gradients, although such studies have focused on relatively few

57 taxa, in particular vascular plants and vertebrates (Chen, Hill, Ohlemuller, Roy, \& Thomas, 2011;

58 Lenoir, Gegout, Marquet, de Ruffray, \& Brisse, 2008; Pauli et al., 2012; Rumpf et al., 2018; Stockli,

59 Wipf, Nilsson, \& Rixen, 2012). Thus, despite many studies showing biodiversity responses to

60 warming, the generality of such responses across taxa remains unclear. For instance, very few

61 studies have reported clear empirical evidence of bryophyte community responses to climate

62 warming (He, He, and Hyvönen 2016; Hudson and Henry 2010, but see Becker-Scarpitta et al.

63 2017; Bergamini, Ungricht, and Hofmann 2009; Outhwaite et al. 2020; Raabe et al. 2010; Vanneste

64 et al. 2017).

65 Understanding variation among taxa in their responses to environmental change is crucial for 66 identifying priorities in conservation. For example, even if one taxonomic group (e.g., vascular

67 plants) is relatively insensitive to environmental change, other co-occurring taxa (e.g., bryophytes

68 and lichens) might be very sensitive (Hudson \& Henry, 2010), with potentially important 
consequences for ecosystem functions (Lindo \& Gonzalez, 2010; Turetsky, 2003). Thus, our

70 limited knowledge base with which to identify the most relevant set of metrics or the taxonomic

71 groups most sensitive to environmental change constrains our ability to set efficient conservation

72 priorities. We operationally define "sensitivity" here as responsiveness: i.e., the degree to which a

73 given community property changes in the face of environmental change.

To assess long-term responses of ecological communities to environmental change, "legacy"

ecological records have been used to provide baselines for comparison with contemporary

resurveys (Chytrý, Tichý, Hennekens, \& Schaminée, 2014; Hédl, Bernhardt-Römermann, Grytnes,

Jurasinski, \& Ewald, 2017; Vellend, Brown, Kharouba, McCune, \& Myers-Smith, 2013). However,

historical botanical studies are strongly biased towards vascular plants, with few data on

bryophytes, due in part to the difficulty of identification (Gignac 2001; He, He, and Hyvönen 2016;

Möls et al. 2013 but see Becker-Scarpitta et al., 2017; Bergamini et al., 2009; Delgado \& Ederra,

81 2013; Outhwaite, Gregory, Chandler, Collen, \& Isaac, n.d.; Vanneste et al., 2017). This is despite the

fact that bryophytes are major contributors to diversity and vegetation cover in many temperate,

boreal or alpine ecosystems, playing an important role in ecosystem functions, such as biomass

Patiño \& Vanderpoorten, 2018; Rydin, 2008; Tuba, Slack, \& Stark, 2011; Turetsky, 2003).

For several reasons we might expect vascular plants and bryophytes to show different responses

to various sources of environmental change (Bagella, 2014; Becker-Scarpitta et al., 2017; Lee \& La

88 Roi, 1979; Möls et al., 2013; Vanneste et al., 2017). Compared to vascular plants, bryophytes are

89 distinguished by their small size, high sensitivity to the moisture and chemistry of their immediate

90 microenvironment (i.e., they are poikilohydric), lower temperature optima for growth, absence of

91 roots and an efficient vascular system, and dispersal via spores (Glime, 2007). These two groups

92 can show contrasted spatial patterns of diversity (Lalanne, Bardat, Lalanne-Amara, Gautrot, \&

93 Ponge, 2008; Mateo et al., 2016). For instance, vascular plants show a clear latitudinal diversity 
94 gradient of decreasing species richness with increasing latitude, while this is not true for

95 bryophytes, for which temperate latitudes are equally diverse as tropical latitudes (Geffert, Frahm,

96 Barthlott, \& Mutke, 2013; Mateo et al., 2016). Some studies have also observed different patterns

97 of community $\beta$-diversity (Kraft et al., 2011; Mateo et al., 2016) with vascular plant communities

98 sometimes showing higher $\beta$-diversity along elevation gradients than bryophytes, suggesting a

99 broader tolerance of bryophyte species to temperature (Glime, 2013; Lee \& La Roi, 1979; Vanneste

100 et al., 2017; Vittoz et al., 2010).

101 General predictions for the effects of warming on vascular plants include declines in the abundance

102 of cold-adapted species, an upward expansion of elevational range limits for warm-adapted

103 species (Rumpf et al., 2018), and an increase of local species richness in area without water-stress

104 (Harrison, 2020; Vellend, Baeten, et al., 2017). Compared to vascular plants, some studies have

105 suggested that changes in bryophyte communities are more strongly influenced by stochastic

106 processes or by micro-environmental variation than macro-environmental conditions (Fenton \&

107 Bergeron, 2013; Pharo \& Vitt, 2000; Raabe et al., 2010). Because bryophytes have wider

108 temperature affinities and higher affinity to micro-environment than macro-environment, we

109 might expect bryophytes to show lower sensitivity to global warming than vascular plants. The

110 consequences of warming for $\beta$-diversity are more difficult to predict given a paucity of studies on

111 this topic (Socolar et al. 2016 but see Nascimbene and Spitale 2017). However, numerical

112 simulations show that species with high dispersal capacity will be favored in areas experiencing

113 strong environmental changes, in which case we might predict a decrease of $\beta$-diversity (Mouquet

114 \& Loreau, 2003) and thus biotic homogenization (Clavel, Julliard, \& Devictor, 2011).

115 As in many parts of the world, eastern Canada has shown a general warming trend over the past

$116 \sim 50$ years, but with a strong east-west gradient in the magnitude of warming in the province of

117 Québec (Yagouti, Boulet, Vincent, Vescovi, \& Mekis, 2008). Becker-Scarpitta, Vissault, and Vellend

118 (2019) showed that the magnitude of temporal changes of vascular plant communities in three 
119 protected areas generally increased from east to west in southern Québec, with greater changes in

120 areas of stronger warming in recent decades. For two of these three parks, the historical data also

121 included bryophytes, thus presenting an opportunity to test for differential sensitivity among taxa

122 to warming. Forillon National Park is located at the eastern tip of the province of Québec where

123 warming has been minimal. In contrast, Mont-Mégantic Provincial Park is in central Québec were

124 the warming trend has been steeper (Savage \& Vellend, 2015; Yagouti et al., 2008).

125 Here we report one of the first studies comparing long-term change of bryophytes and vascular

126 plants communities in sites with contrasting long-term warming trends. In each of the two parks,

127 we revisited $\sim 50$ legacy vegetation plots initially surveyed in the 1970 s, applying the same

128 methods as the original surveys. To minimize potentially confounding factors, plots were selected

129 in mature forest ecosystems that have not experienced major natural or anthropogenic

130 disturbances during the time between surveys. We test two main hypotheses: (i) For both

131 bryophytes and vascular plants, the park with a stronger warming trend (Mont-Mégantic) has

132 experienced greater long-term community changes than the park with a weaker warming trend

133 (Forillon); (ii) Vascular plant communities are more sensitive than bryophyte communities to

134 climate warming. For each taxon in each park, we quantified the magnitude of changes in (a)

135 species' distributions along the elevation gradient, (b) species richness, and (c) community

136 composition.

$137 \underline{\text { Methods }}$

$138 \quad$ Study site

139 Our two study sites were located in eastern Canada: Forillon National Park in eastern Québec $140\left(48^{\circ} 54^{\prime} \mathrm{N}, 64^{\circ} 21^{\prime} \mathrm{W}\right)$, and Mont-Mégantic Provincial Park in central Québec $\left(45^{\circ} 27^{\prime} \mathrm{N}, 71^{\circ} 9^{\prime} \mathrm{W}\right)$.

141 Neither park has experienced logging or forest management over the last $\sim 40$ years. Forillon

142 National Park was created in 1970 and covers $245 \mathrm{~km}^{2}$; our study plots ranged in elevation from 
$143 \sim 50$ to $500 \mathrm{~m}$ a.s.l. The vegetation at Forillon is dominated by a mixture of northern tree species

144 such as Abies balsamea (L.) Mill., Picea glauca (Moench) Voss and Betula papyrifera Marsh. at 145 higher elevations, and Acer saccharum Marsh. and Betula alleghaniensis Britt. at lower elevations 146 (Majcen, 1981). Mont-Mégantic Provincial Park was created in 1994 (logging ceased in the 1960s 147 during park planning) and covers $\sim 55 \mathrm{~km}^{2}$. Our study plots span an elevational gradient from $148 \sim 460$ and $1100 \mathrm{~m}$ a.s.l., along which the vegetation gradient strongly resembles that in Parc 149 Forillon: from temperate deciduous forests dominated by Acer saccharum., Fagus grandifolia Ehrh. 150 and Betula alleghaniensis, to boreal forest dominated by Abies balsamea, and Picea rubens Sargent, 151 Silva. (Marcotte \& Grandtner, 1974).

\section{$152 \quad$ Data set}

153 Original vegetation surveys in both parks were conducted using phytosociological methods 154 (Majcen, 1981; Marcotte \& Grandtner, 1974). In each plot, authors listed all species in different 155 strata (canopy trees, shrubs, herbs and ground bryophytes) and for each species assigned an 156 abundance coefficient following (Braun-Blanquet, Roussine, \& Nègre, 1952). For vascular plants, 157 our analyses focused on shrubs and herbs, which were combined into a single "understorey" 158 stratum. All bryophyte species that were found on the ground were recorded (i.e. on organic litter 159 and soil surface mineral layers, not including deadwood, tree trunks and rocks); these surveys did 160 not involve intensive searches for individual stems of rare species within moss carpets (i.e., some 161 locally rare species were missed). After consulting with botanists active in Québec in the 1960s 162 and 1970s (C. Ansseau, Z. Majcen, personal communication, 2014), we are confident in comparing 163 Braun-Blanquet indices across time for vascular plants (for further detail see Becker-Scarpitta, 164 Vissault, and Vellend 2019) but not for bryophytes, given uncertainty in the definition of the area 165 over which percent cover was evaluated (microhabitats vs. entire plots). To maximize 166 comparability across time and taxa, we used presence-absence data for both vascular and 167 bryophyte species in all statistical analyses. 
168 Our approach to plot relocation is described in Becker-Scarpitta et al., (2019). In short, original

169 survey plots were not permanently marked, although locations were reported in maps and/or

170 tables, such that plots are considered “semi-permanent”. In both parks, original surveyors sampled

171 mature forests where spatial heterogeneity was relatively low. We selected plot locations for

172 recent surveys using original plot maps and environmental descriptions (elevation, slope, aspect),

173 and observations in the field to maximize the match of current and historical abiotic conditions. In

174 Mont-Mégantic, recent surveys included all plots within the current park boundary. Not all plot

175 locations in Forillon were accessible, and plot selection for the recent surveys used the following

176 criteria: (i) plots occurred in forest, excluding swamps or bogs; (ii) plots were accessible via $<3-4$

177 hours hiking off of established trails; (iii) plots had not obviously experienced major natural

178 disturbances (e.g., storm, fire, or insect outbreak); (iv) in the original survey the plots were

179 sampled in mature stands that have since maintained forest cover (i.e., no early successional 180 dynamics in the intervening period) (Becker-Scarpitta et al., 2019).

181 Original surveys in Forillon Park were conducted in June-September 1972 in 256 vegetation plots

$182\left(500 \mathrm{~m}^{2}\right)$ (Majcen, 1981). We resurveyed 49 plots during July and August of 2015. Original surveys

183 in Mont-Mégantic were conducted in 1970 in 94 plots, roughly half of which fall outside the current

184 park boundaries. Plots were $400 \mathrm{~m}^{2}$ in coniferous forest and $800 \mathrm{~m}^{2}$ in broadleaved forests

185 (Marcotte \& Grandtner, 1974). We resurveyed the 48 plots falling within the current park limits

186 at Mont-Mégantic for vascular plants in 2012 (see Becker-Scarpitta et al., 2019) and for bryophytes

187 during June and July 2014 (reported in the present study). We harmonized the taxonomy across

188 both parks and periods (see below), so the Mont-Mégantic data are not precisely the same as

189 reported in Savage \& Vellend, (2015), but they are exactly the same as in Becker-Scarpitta et al.,

190 (2019) except transformed into presence-absence. Data are stored in forestREplot database

191 (http://www.forestreplot.ugent.be/) under the code : N_AM_005 for Mont-Mégantic and

192 N_AM_008 for Forillon. 


\section{$\underline{\text { Taxonomical database }}$}

194 Our taxonomical reference was the Taxonomic Name Resolution Service v4.0 (assessed in Feb

195 2017: http://tnrs.iplantcollaborative.org) for vascular plants and Flore des bryophytes du

196 Québec-Labrador (Faubert, 2012, 2013, 2014) for bryophytes.

197 Our data set was collected by four different survey teams: one for each of the two original surveys:

198 Forillon: Majcen, (1981); Mont-Mégantic: Marcotte \& Grandtner, (1974); one for the recent Mont-

199 Mégantic vascular plant survey: Savage \& Vellend, (2015); and one for the recent Mont-Mégantic

200 bryophyte survey and for the recent survey of both taxa at Forillon (A. Becker-Scarpitta and

201 assistants). Most plants were identified to the species level in the same way across surveys, so for

202 these taxa the only harmonization step was to standardize names. Coarser levels of taxonomic

203 resolution were used in some but not all surveys for certain species (e.g., a pair of similar species

204 not identified to the species level), and for other species (e.g., spring ephemeral species) the timing

205 of different surveys created doubt about the likelihood of comparable detection. In these

206 situations, comparability was maximized by using the coarser level of resolution applied to all data

207 sets, or by removing species (see Appendix S1 for details on taxonomic standardization). All

208 specimens identified at the species level were deposited in the Marie-Victorin herbarium

209 (Université de Montréal, Canada.) and all locations were entered into the GBIF database (GBIF -

210 https://www.gbif.org/).

\section{$211 \quad$ Statistical analysis}

212 All statistical analyses were performed in R v.3.4.2 (R Foundation for Statistical Computing 2018).

213 To test for upward elevational shifts in species distributions at Forillon and Mont-Mégantic, we

214 calculated the mean elevation across all occurrences of a given species in each time period. For

215 vascular plants and bryophytes separately, we then conducted linear mixed effect models (LMM,

216 function Imer, package 'Ime4' v.1.1-14, Bates, Mächler, Bolker, \& Walker, 2015) testing the effect 
217 of time on mean elevation; each species was weighted by the sum of its occurrences in each survey,

218 and species was included as a random effect to account for the paired sampling structure of the

219 data (i.e. each species observed in each time period).

220 To test for differences between taxa and parks in terms of the temporal change in plot-level species

221 richness ( $\alpha$-diversity) we first calculated the log ratio, $\ln$ (recent richness/original richness), for

222 each taxa-park combination, and ran an ANOVA model with each combination of park and taxa as

223 factors. Secondly, we explored separately the temporal trend of $\alpha$-diversity of both bryophytes

224 and vascular plants within parks using LMMs with time, elevation and the time*elevation

225 interaction (if significant) as fixed effects and with plot ID as a random effect.

226 We then explored temporal change in $\beta$-diversity using two different frameworks. First, we

227 assessed the multivariate homogeneity of group dispersions using an asymmetric binary Jaccard

228 dissimilarity (used for presence-absence data), with significance testing via permutation

229 (PERMDISP, function betadisper, package 'vegan' v.2.4-4; Anderson, Ellingsen, \& McArdle, (2006)).

230 A decrease in the multivariate distance between plots and the time-specific centroid is interpreted

231 as biotic homogenization, while an increase indicates biotic differentiation. Second, to explore the

232 components of temporal change in species composition, we calculated the temporal pairwise $\beta$ -

233 diversity as the binary Jaccard dissimilarity between the recent and original surveys for each plot.

234 Temporal $\beta$-diversity was decomposed into two components: turnover due to species

235 replacements (T) and nestedness (N) (function beta.temp, package 'betapart'; Baselga, 2012;

236 Baselga \& Leprieur, 2015).

237 To examine changes in community composition over time, we used permutational analysis of 238 variance (PERMANOVA, Anderson, 2001) with Jaccard distances using 999 permutations (function 239 adonis, package 'vegan'). We used the $\mathrm{R}^{2}$ values from the PERMANOVA models as a quantification 240 of the magnitude of temporal change in order to compare among parks. We used non-metric 
241 multidimensional scaling (nMDS) with Jaccard distances for visualization (function metaMDS,

242 package 'vegan'). Finally, within each park, we identified indicator species for each time period

243 using the IndVal procedure (function multipatt, package 'indicspecies'; De Cáceres, Legendre, \&

244 Moretti, 2010).

\section{$245 \quad$ Results}

\section{Species distributions along elevation gradients}

247 Among the four taxa-park combinations, vascular plants at Mont-Mégantic was the only one

248 showing a significant upward shift in mean species elevations over time (Table 1a, Fig. 1). Data

249 for vascular plants at Mont-Mégantic were already presented in Becker-Scarpitta et al., (2019), and

250 it is important to note that patterns reported here are not quantitatively the same, given the use

251 of the presence-absence data in this study.

252 Consistent with our hypothesis, we detected no elevational distribution shift for either vascular

253 plants or bryophytes in Forillon, where the warming trend has been weak, nor for bryophytes at

254 Mont-Mégantic. Despite the lack of trends in average elevation for bryophytes, there was

255 substantial variation among species (less so than for vascular plants) (Table 2, Fig. 1). This

256 observation is reflected in the strength of correlations between original and recent mean species

257 elevations, which was lower for bryophytes (Forillon Pearson $r$ correlation $=0.327$; Mont-

258 Mégantic $r=0.577$ ) than for vascular plants (Forillon $r=0.518$; Mont-Mégantic $r=0.729$ ). See

259 Appendix S2 for mean elevations and sums of occurrences for each species in each survey. 
260 Table 1 - Analyses of temporal changes in (a) average species elevation, (b) plot-level species

261 richness ( $\alpha$-diversity) along elevational gradients, and (c) multivariate $\beta$-diversity along elevation

262 gradients (see Table 3 for other $\beta$-diversity analyses). For (a) and (b), results are shown for linear

263 mixed models; in (a) species were weighted by the sum of occurrences across both original and

264 recent surveys. In (c), $\beta$-diversity was measured as the distance of plots to time-specific centroids

265 (space defined by Jaccard dissimilarities) and tested using PERMIDSP. The sign of the relation is

266 indicated in brackets only for significant effect. $\mathrm{R}^{2} \mathrm{~m}$ is the marginal coefficient of determination,

267 measuring the proportion of variance explained by fixed effects; $\mathrm{R}^{2} \mathrm{c}$ is the conditional coefficient

268 of determination, giving the proportion of variance explained by both fixed and random effects, $p$

$269<0.05$.

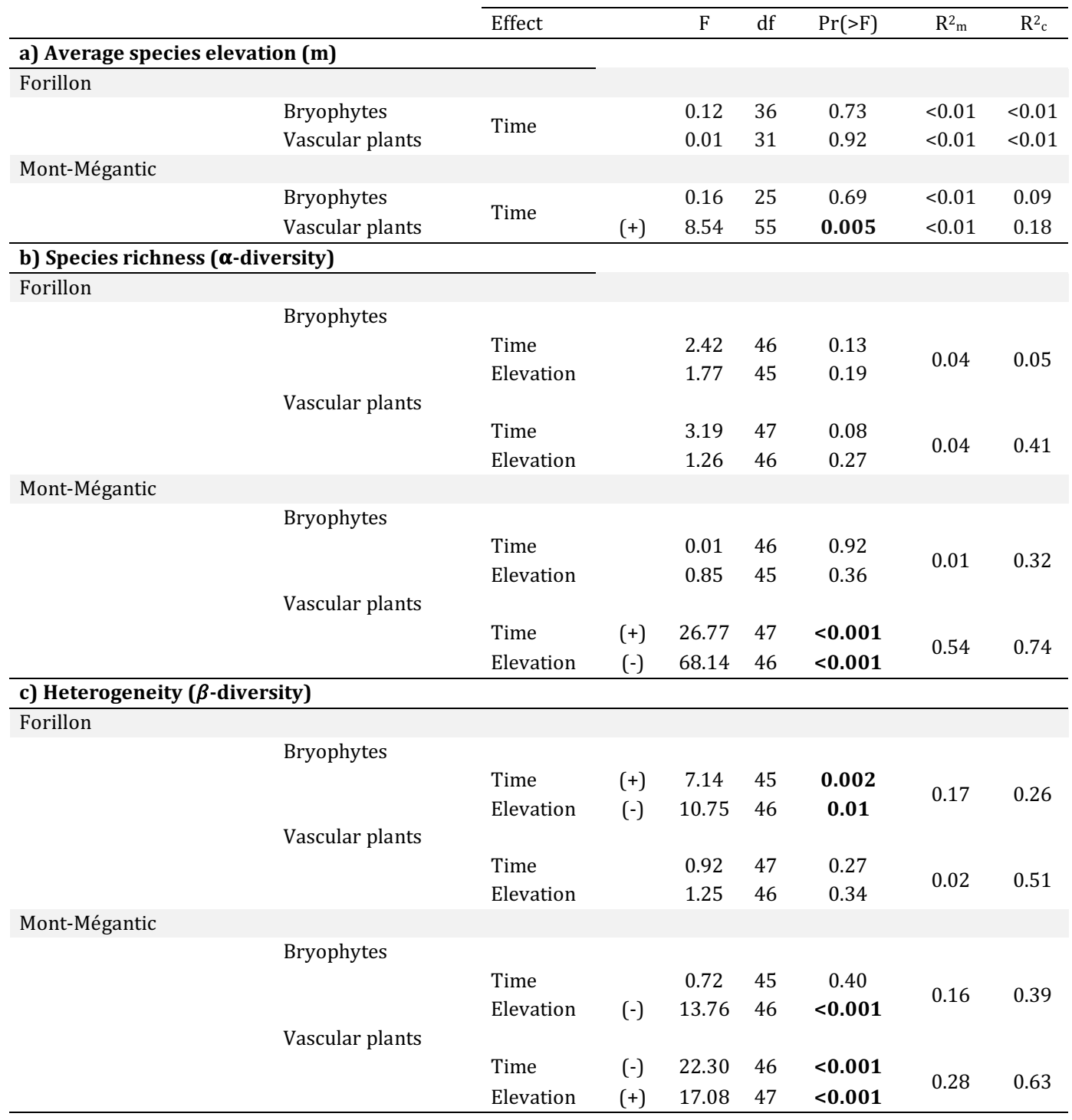


Forillon
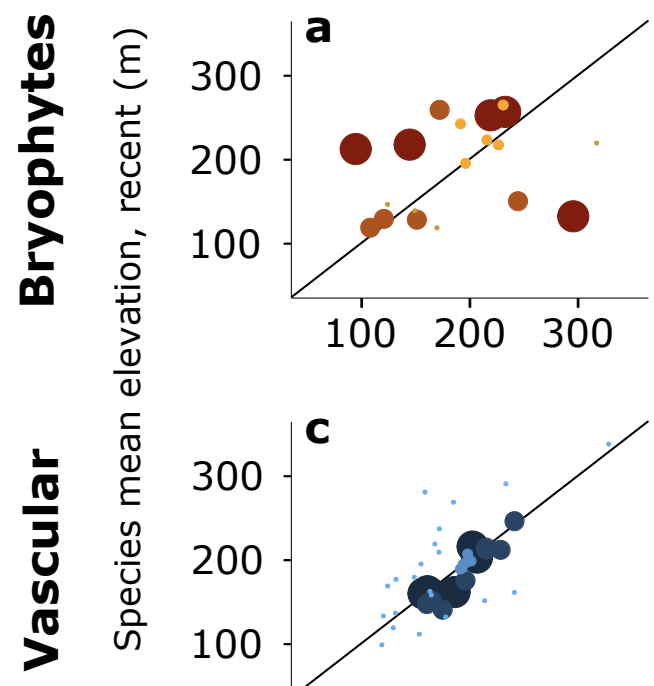
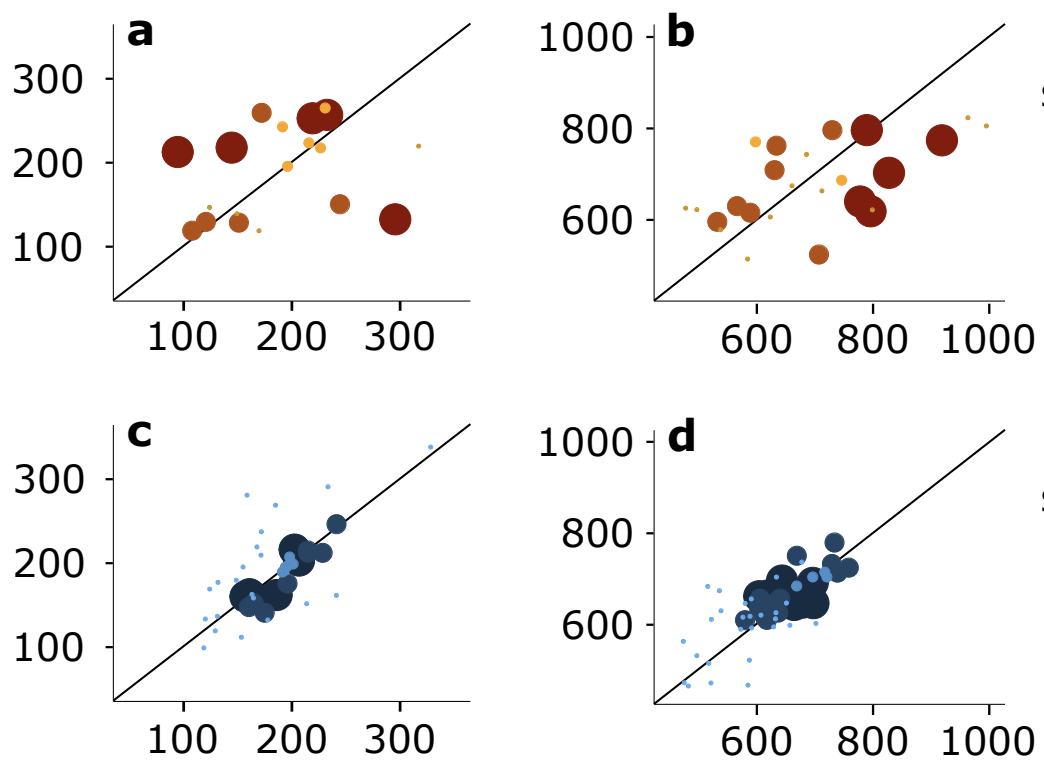

Species mean elevation, original $(\mathrm{m})$

271 Figure 1 - Species distributions along elevation gradients in two-time periods. a) Bryophytes in

272 Park Forillon ( $\mathrm{n}=19$ species); b) Bryophytes at Mont-Mégantic ( $\mathrm{n}=25$ species); $\mathrm{c}$ ) Vascular plants

273 in Park Forillon ( $n=42$ species); d) Vascular plants at Mont-Mégantic ( $n=64$ species). All species

274 present in both original and recent surveys were included; the size of each point is proportional to

275 the number of occurrences summed across the two survey years for a given species. Diagonals

276 indicate 1:1 line (i.e. no changes over time). The only significant increase of mean species elevation

277 over time was for vascular plants in Mont-Mégantic (panel d; see also Table 1a).

\section{$278 \quad$ Temporal changes in species richness}

279 At Forillon, the total number of bryophyte species across plots was greater in the recent survey

280 (57 species) than in the original survey (42 species); 15 species from the original survey were not

281 found while 30 new species were observed (Table 2 and Appendix S2 for species occurrences).

282 Conversely, the total number of vascular plants at Forillon declined over time (original survey = 
28383 vs. recent $=65$ species), with 27 original species not found in the recent survey and 9 new

284 species added (Table 2).

285 At Mont-Mégantic we found similar trends between vascular plants and bryophytes. In the recent

286 survey, there was an increase in the overall number of bryophytes species (original survey $=46$

287 vs. recent $=55$ species), with 16 species lost and 25 gained. The total number of vascular plant

288 species also increased (from 87 species to 92 species), with 8 species lost and13 gained.

289 Overall, the only strong significant temporal change detected in mean plot-level species richness

290 was an increase for vascular plants at Mont-Mégantic (mean log ratio of species richness $=0.3$;

$29195 \% \mathrm{CI}[0.16,0.44] ; \mathrm{t}=4.40 ; \mathrm{df}=47 ; \mathrm{p}<0.001)$, where richness significantly declined with elevation

292 (Fig. 2d, Table 1b; see also (Becker-Scarpitta et al., 2019). For vascular plants at Forillon and for

293 bryophytes in both parks, species richness at the plot level showed neither changes over time nor

294 any relationship with elevation (Table 1a-b, Fig. 2 a-b-c).

296 Table 2 - Temporal changes in total species numbers, plot-level species richness ( $\alpha$-diversity) and

297 mean species elevation for bryophytes and vascular plants in Forillon Park and Mont-Mégantic

298 Park. The total number of species observed across all plots is divided into shared, lost, or gained

299 species between the original and recent surveys. For plot-level richness and mean species

300 elevation, mean \pm SE are reported. Bold values indicate significant statistical differences $(\mathrm{p}<0.05$,

301 see Table $1 \mathrm{~b}$ for statistical tests). Temporal changes in "Total species number" were not tested

302 statistically.

\begin{tabular}{|c|c|c|c|c|c|c|c|c|c|c|c|c|}
\hline & & \multicolumn{5}{|c|}{ Total species number } & \multicolumn{3}{|c|}{$\alpha$-diversity } & \multicolumn{3}{|c|}{ Mean species elevation } \\
\hline & & Original & Recent & Shared & Lost & Gained & Original & Recent & $n$ plot & Original & Recent & $n \mathrm{sp}$ \\
\hline \multicolumn{13}{|l|}{ Forillon } \\
\hline & Bryophytes & 42 & 57 & 27 & 15 & 30 & $5.4 \pm 0.5$ & $6.3 \pm 0.4$ & 47 & $208.8 \pm 9.5$ & $204 \pm 9.8$ & 19 \\
\hline & Vascular plants & 83 & 65 & 56 & 27 & 9 & $18.2 \pm 1$ & $16.4 \pm 1$ & 48 & $186.3 \pm 5.5$ & $186.8 \pm 5.6$ & 42 \\
\hline \multicolumn{13}{|l|}{ Mégantic } \\
\hline & Bryophytes & 46 & 55 & 30 & 16 & 25 & $5.6 \pm 0.4$ & $5.5 \pm 0.4$ & 47 & $702.5 \pm 21.2$ & $702.5 \pm 21.2$ & 25 \\
\hline & Vascular plants & 87 & 92 & 79 & 8 & 13 & $21.2 \pm 1$ & $27 \pm 1$ & 48 & $629.2 \pm 7.3$ & $642.5 \pm 7.1$ & 64 \\
\hline
\end{tabular}


Forillon

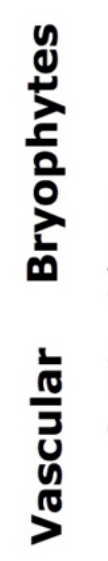

Figure 2 - Temporal changes of plot-level species richness ( $\alpha$-diversity) along elevation gradients.

306 The only significant increase of $\alpha$-diversity over time was for vascular plants in Mont-Mégantic

307 (panel d; see also Table 1b).

\section{$308 \quad$ Temporal shift in community composition and heterogeneity}

309 Consistent with our hypotheses, we found significant temporal changes in vascular plant $\beta$-diversity

310 and community composition at Mont-Mégantic (Figs. 3 \& 4, Table 3), where climate warming has been

311 pronounced, as previously reported (Becker-Scarpitta et al., 2019). However, we found unexpected

312 results for bryophytes: a significant increase of multivariate dispersion ( $\beta$-diversity) over the past 40

313 years at Forillon but not at Mont-Mégantic (Table 3, Fig. 3). The observed increase in the distance of

314 plots from multivariate centroids at Forillon was consistent along the whole elevation gradient (Table

315 1c, Fig. 4). The decomposition of the temporal changes in bryophyte community composition showed

316 a greater contribution of turnover (Forillon $=0.70$, Mont-Mégantic $=0.86$ ) than nestedness (Forillon

$317=0.11$, Mont-Mégantic $=0.03$, Table 3). For vascular plants at Mont-Mégantic but not at Forillon we

318 found a significant decrease of $\beta$-diversity over time, consistent along the elevational gradient (Table 
319 3, Figs. 3 \& 4). Turnover was also the main driver of temporal community change for vascular plants

320 (Table 3).

321 For both sites and taxa, we found significant temporal shifts in community composition (Figs. 3 \& 4,

322 Table 3), although the effect was weak in all analyses. As predicted, the magnitude of the vascular

323 plant compositional shift was greater for Mont-Mégantic $\left(\mathrm{R}^{2}=4 \%\right)$ than Forillon $\left(\mathrm{R}^{2}=2 \%\right.$, Table 3$)$.

324 However, bryophyte communities experienced an equal magnitude of compositional shift for both

325 Forillon and Mont-Mégantic $\left(\mathrm{R}^{2}=7 \%\right)$. Moreover, compositional shifts were greater for bryophytes

326 than for vascular plants at both sites, contrary to our hypothesis (Table 3, Fig. 3).

327 Table 3 - Temporal changes in two $\beta$-diversity metrics and community composition between original

328 and recent surveys for vascular plants and bryophytes in Forillon Park and Mont-Mégantic Park.

329 "Multivariate dispersion" was calculated (based on Jaccard's dissimilarity) as the mean distance of

330 plots to time-specific centroids and analyzed using PERMDISP. "Temporal $\beta$-diversity" ( $\beta$ j) was

331 calculated as the pairwise Jaccard's dissimilarity between the recent and original survey and

332 decomposed into components of turnover (T) and nestedness (N). Changes in community

333 composition were analyzed using PERMANOVA. $\mathrm{R}^{2}$ is the proportion of variation in community

334 composition explained by time. Statistical significance levels were calculated with 999 permutations, $335 \mathrm{p}<0.05$.

\begin{tabular}{|c|c|c|c|c|c|c|c|c|c|c|c|}
\hline & & \multicolumn{4}{|c|}{ Multivariate dispersion } & \multicolumn{3}{|c|}{ Temp. $\beta$-diversity } & \multicolumn{3}{|c|}{ Community composition } \\
\hline & & Original & Recent & $\mathrm{F}$ & $\operatorname{Pr}(<\mathrm{F})$ & $\beta \mathbf{j}$ & $\mathrm{T}$ & $\mathrm{N}$ & $\mathrm{R}^{2}$ & $\mathrm{~F}$ & $\operatorname{Pr}(<\mathrm{F})$ \\
\hline \multicolumn{12}{|l|}{ Forillon } \\
\hline & Bryophytes & 0.54 & 0.59 & 4.32 & 0.04 & 0.81 & 0.70 & 0.11 & 0.07 & 6.57 & $<0.001$ \\
\hline & Vascular plants & 0.45 & 0.44 & 0.55 & 0.47 & 0.52 & 0.37 & 0.16 & 0.02 & 1.74 & 0.05 \\
\hline \multicolumn{12}{|l|}{ Mégantic } \\
\hline & Bryophytes & 0.62 & 0.61 & 0.44 & 0.52 & 0.90 & 0.86 & 0.03 & 0.07 & 7.02 & $<0.001$ \\
\hline & Vascular plants & 0.50 & 0.44 & 9.23 & 0.003 & 0.54 & 0.39 & 0.16 & 0.04 & 0.43 & 0.002 \\
\hline
\end{tabular}




\section{Forillon Mégantic}
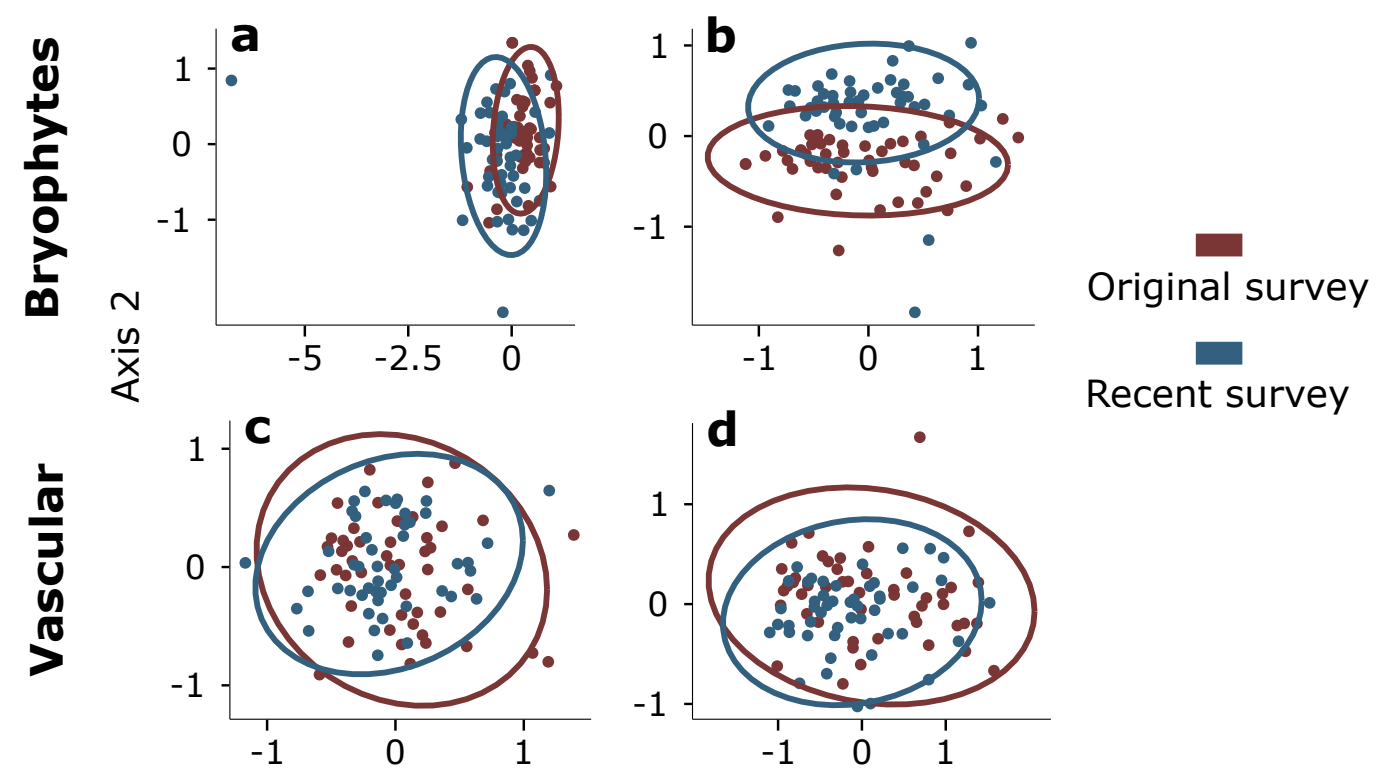

Axis 1

337 Figure 3 - nMDS ordinations (based on Jaccard's dissimilarity) of vascular plant and bryophyte

338 communities across time in Forillon and Mont-Mégantic. In panel (a), the left-most plot was

339 composed of a single unique species very rare elsewhere; PERMDISP and PERMANOVA results were

340 qualitatively similar with and without this plot. Bryophytes at Forillon (panel a) show significant

341 increase in beta-diversity while vascular plant in Mont-Megantic (panel d) show significant decrease

342 of beta-diversity (see also Table 1c). 
Forillon

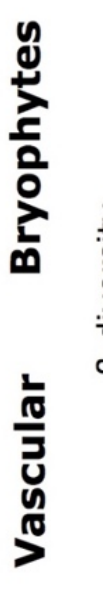

a

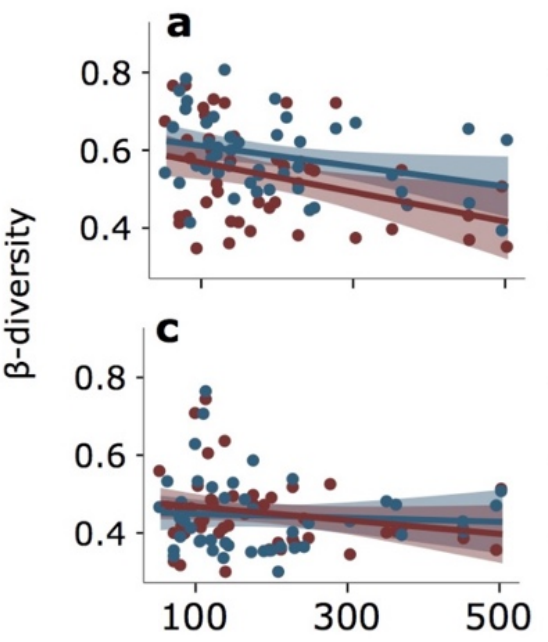

Mégantic

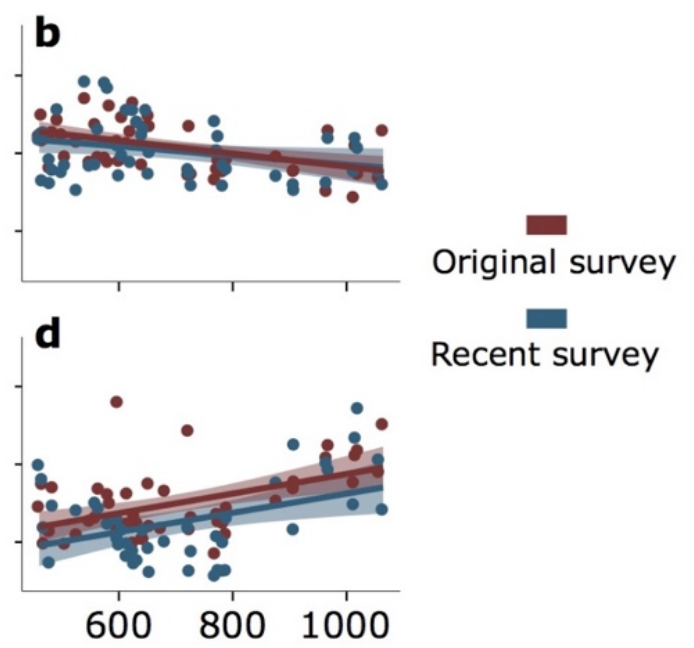

Plot elevation $(\mathrm{m})$

344 Figure 4 - Temporal changes of $\beta$-diversity along elevational gradients for bryophytes (a-b) and

345 vascular plant communities (c-d) at Forillon and Mont-Mégantic. $\beta$-diversity is here calculated for 346 each plot as the multivariate distance to time-specific centroids (Jaccard's dissimilarity; see Table 1c

347 for statistical analyses).

349 In terms of bryophyte indicator species, Dicranum fuscescens was associated with original surveys for

350 both parks, while Dicranum polysetum was associated with the two recent surveys (Table 4). These

351 two species are morphologically very different to confuse them. Other indicator bryophytes for either

352 time period were unique to one or the other park. For vascular plants, recent surveys were associated

353 with two of only three non-native species in the data set: Galeopsis tetrahit (only at Mont-Mégantic)

354 and Epipactis helleborine (both parks) (Table 4). Recent surveys at Mont-Mégantic were also

355 associated with two species of Carex and the fern Dennstaedtia punctilobula. 
356 Table 4 - Indicator species of bryophytes and vascular plants associated with original and recent 357 surveys at Forillon and Mont-Mégantic. Indicator values were considered significant if $\mathrm{p}<0.05$

358 (calculated with 999 permutations).

\begin{tabular}{|c|c|c|}
\hline & Bryophytes & Vascular plants \\
\hline \multicolumn{3}{|l|}{ Forillon } \\
\hline Original & Dicranum fuscescens & $\begin{array}{l}\text { Lycopodium annotinum } \\
\text { Galium triflorum }\end{array}$ \\
\hline Recent & $\begin{array}{l}\text { Dicranum montanum } \\
\text { Dicranum polysetum } \\
\text { Brachythecium campestre } \\
\text { Pseudoleskeella tectorum }\end{array}$ & $\begin{array}{l}\text { Gymnocarpium disjunctum } \\
\text { Sambucus racemosa } \\
\text { Epipactis helleborine }\end{array}$ \\
\hline \multicolumn{3}{|l|}{ Mégantic } \\
\hline Original & $\begin{array}{l}\text { Brotherella recurvans } \\
\text { Dicranum fuscescens } \\
\text { Paraleucobryum longifolium } \\
\text { Hypnum pallescens } \\
\text { Bryhnia novae-angliae } \\
\text { Brachythecium reflexum }\end{array}$ & $\begin{array}{l}\text { Osmunda claytoniana } \\
\text { Botrychium virginianum }\end{array}$ \\
\hline Recent & $\begin{array}{l}\text { Atrichum altecristatum } \\
\text { Hylocomiastrum umbratum } \\
\text { Dicranum polysetum } \\
\text { Hypnum curvifolium }\end{array}$ & $\begin{array}{l}\text { Dennstaedtia punctilobula } \\
\text { Carex arctata } \\
\text { Carex deweyana } \\
\text { Circaea alpina } \\
\text { Galeopsis tetrahit } \\
\text { Epipactis helleborine }\end{array}$ \\
\hline
\end{tabular}

\section{Discussion}

360 Most long-term legacy studies have been conducted on vascular plant communities (Verheyen et al., 361 2017), so it remains unknown whether bryophytes show similar or different responses to shared

362 environmental changes. More broadly, we have limited knowledge of how different taxonomic groups

363 respond to long-term environmental change. Thanks to an extensive resurveying of plots with legacy

364 data we quantified community changes over $\sim 40$ years for both bryophytes and vascular plants in

365 two protected natural areas in eastern Canada with contrasting recent warming trends. Temporal

366 changes in vascular plant communities were consistent with the warming hypothesis, but this was

367 not the case for bryophytes. We also did not find clear support for the hypothesis that vascular plants

368 would show greater sensitivity to environmental change (assumed to be dominated by climate

369 warming at Mont-Mégantic), with results depending on the metric of community change. As predicted 
370 for the area with a strong warming trend (Mont-Mégantic), we found a significant upward shift of

371 vascular plant distributions but no change for bryophyte distributions (Table 1a, Fig. 1). However,

372 the higher magnitude of changes in bryophyte community composition at both sites was contrary to

373 our prediction (Table 3, Fig. 3).

\section{$374 \quad$ Patterns along the gradient of warming trends}

375 Consistent with the abundance-based results in Becker-Scarpitta et al., (2019), for vascular plants we

376 found support for the hypothesis that areas with greater warming should experience stronger

377 community changes than areas with weaker warming trends. At Mont-Mégantic, where the warming

378 trend has been strongest, we found a clear pattern for vascular plants of upward shifts in elevational

379 distributions (Table 1a, Fig. 1), a significant increase of $\alpha$-diversity (Tables 1b \& 2, Fig. 2), a stronger

380 shift in community composition than in Forillon (Table 3, Fig. 3) and a significant decrease of $\beta$ -

381 diversity (Table 3, Fig. 4). At Forillon, where the warming trend has been weaker, we found neither

382 shifts in elevational distributions nor changes of $\alpha$-diversity for either vascular plants or bryophytes

383 (Table s1a-b \& 2, Figs. 1 \& 2). The upward shift in elevation of vascular plants in response to warming

384 is in line with many other studies (Bertrand et al., 2011; Chen et al., 2011; Lenoir et al., 2008). The

385 temporal increase of diversity of vascular plant in Mont-Mégantic is also coherent with the prediction

386 that warming should lead to increased local diversity in areas without severe moisture stress

387 (Harrison, 2020; Vellend, Baeten, et al., 2017).

388 Our results suggest that a temperature increase of $1-2{ }^{\circ} \mathrm{C}$ does not have as strong an impact on the

389 local diversity and distributions of bryophytes as it does for vascular plants. This interpretation is

390 also supported by the absence of any relationship between bryophyte richness and elevation in the

391 two parks (Table 1b, Fig. 2) and consistent with previous results (Bruun et al., 2006; Grytnes,

392 Heegaard, \& Ihlen, 2006; Odland, Reinhardt, \& Pedersen, 2014 but see Vittoz et al., 2010). The

393 decrease of $\beta$-diversity over time for vascular plants at Mont-Mégantic supports the hypothesis that 
394 warming might cause biotic homogenization (Socolar et al., 2016; Urban, 2015). Note that this result

395 using presence-absence data was different to the result in Becker-Scarpitta et al., (2019) using

396 untransformed abundance data (for which we found no homogenization), but similar to the finding

397 of homogenization using fourth-root transformed abundances in Savage \& Vellend, (2015). These

398 results collectively illustrate that the locally dominant species - whose influence is minimized or

399 eliminated via fourth-root or presence-absence transformation - can mask homogenization created

400 by species of lower abundance. This result highlights how ecological conclusions are dependent on

401 the data transformation, even with widely used diversity metrics.

\section{Sensitivity of bryophytes vs, vascular plants}

403 We cannot draw strong conclusions about which of bryophytes or vascular plants is more or less

404 sensitive to environmental change in eastern Canada: results depended on which community

405 property was being investigated. Vascular plants showed more prominent upward elevational

406 distribution shifts and richness increases (Tables 1a-b \& 2, Figs. 1 \& 2) while bryophytes experienced

407 stronger shifts in community composition and no difference in the magnitude of compositional

408 changes between the two parks with contrasting warming trends (Table 3, Fig. 3).

409 The lack of directional shifts in bryophytes' elevational distributions at either site (Table 1a, Fig. 1) is

410 coherent with other results showing that bryophyte species have broader elevation ranges - and

411 therefore presumably reduced sensitivity to temperature change - compared to vascular plants (Lee

412 \& La Roi, 1979; Vanneste et al., 2017; Vittoz et al., 2010). This may be due to the ability of bryophytes

413 to photosynthesize under larger ranges of temperature than vascular plants (Glime, 2013) and their

414 frequent occurrence in microhabitats (e.g., defined by micro-topography) buffered from macro-

415 environmental changes (Raabe et al., 2010). The decrease of bryophyte $\beta$-diversity with elevation in

416 both parks (Table 1, Fig. 4) suggests that bryophyte species found at high elevation (i.e. in boreal

417 forests) tend to be common along the entire gradient, while bryophytes occurring at low elevation 
418 are absent from high elevations which is coherent with other patterns (Lee \& La Roi, 1979; Slack,

419 1977).

420 Potential non-climatic drivers of vegetation change

421 Our sites were chosen specifically due to their contrasting warming trends and lack of other obvious

422 major drivers of vegetation change, but there are certainly other possible drivers of ecological change

423 that might play a role in this region. Among the indicator species of recent surveys, two were non-

424 native: Galeopsis tetrahit and Epipactis helleborine, the latter of which has increased considerably in

425 recent decades throughout its North American range, even in western Canada (Marie-Victorin, 1997;

426 McCune \& Vellend, 2013). As such, some vegetation changes might be due simply to protracted

427 periods of non-native species expansions, regardless of local environmental change. Another

428 potential factor is changes in white-tailed deer browsing, which has increased over the past century

429 in much of North America (Côté, Rooney, Tremblay, Dussault, \& Waller, 2004). The indicator species

430 of the recent survey at Mont-Mégantic include species known to benefit from high levels of deer

431 browsing: Dennstaedtia punctilobula and Carex spp. (Augustine \& Decalesta, 2003; de la Cretaz \&

432 Kelty, 2002; Frerker, Sabo, \& Waller, 2014; Rooney, 2009). Interestingly, at Forillon deer are actually

433 thought to have decreased in abundance due to the expansion of the coyote population in the 1970s

434 (UQCN, 2005), and we found no such species associated with recent surveys in Forillon Park.

435 Our most difficult result to interpret was the strong species turnover of bryophyte communities at

436 Forillon, which has not experienced strong long-term trends in temperature, precipitation, or

437 atmospheric nutrient deposition (Commission Joint International, 2014; Hember, 2018). We can only

438 speculate and offer hypotheses about potential non-climatic drivers of bryophyte community change.

439 First, as in all legacy studies, there is the potential for observer biases due to (i) different sampling

440 effort between original and recent surveys, or (ii) species' identification errors. It seems highly likely

441 that detection probabilities and the potential for identification errors are greater for bryophytes than

442 for vascular plants, although we have no reason to suspect this caused systematic increases or 
443 decreases of particular species frequencies (necessary to explain overall compositional shifts). We

444 paid very close attention to repeating the original survey methods, focusing on the visually obvious

445 species in a given microsite (i.e., not examining each individual moss stem closely on the field), and

446 the lack of any difference over time in local richness (Fig. 2a-b) suggests comparable species'

447 detection abilities in the two surveys. Although we cannot exclude the possibility that a real richness

448 change was cancelled out by a change in survey effort, we have no reason to suspect this rather

449 unlikely coincidence. Second, given uncertainty in the comparability of abundance estimates across

450 time for bryophytes, we also decided to use presence-absence data. In short, changes in observer

451 effort seem highly unlikely to account for the temporal change in species composition. Furthermore,

452 our procedure to homogenize taxonomy across data sets was quite conservative in order to reduce

453 bias due to misidentifications.

454 One potential hypothesis to explain compositional change over time in bryophyte communities

455 relates to the history of park protection. Forillon Park was established (and so protected) only two 456 years before the original survey was conducted, and parts of the park previously included homesteads

457 (i.e., non-forest land uses). Mont-Mégantic was established as a park more recently (1994), but 458 logging activities (the only prominent land use) ceased $~ 15$ years before the original survey. Although 459 plot selection focused only on non-disturbed forests, metacommunity dynamics involving dispersal 460 of species from sites undergoing rapid succession may have caused local shifts in composition and 461 increased $\beta$-diversity. It has been previously shown that managed forests tend to have a lower $\beta$ 462 diversity than protected forests (Kaufmann, Hauck, \& Leuschner, 2017). The increase in bryophyte $\beta$ 463 diversity might partially be due to the recovery of natural forest that occurring in the 1970s.

464 There is also the possibility that changes in bryophyte communities resulted from interactions with 465 changing vascular plant communities. Studies have shown that bryophyte diversity and abundance 466 can be negatively correlated with total vascular plant biomass (Virtanen, Eskelinen, \& Harrison, 467 2017), cover (Jiang, Liu, Song, Yu, \& Shao, 2015) or abundances (Jägerbrand, Kudo, Alatalo, \& Molau, 
2012). While we have documented an increase of vascular plant species richness at Mont-Mégantic

469 (Tables 1 b \& 2, Fig. 2), we do not have data on vascular plant biomass. If bryophytes are highly

470 sensitive to vascular plant community properties, subtle changes for vascular plants could translate

471 into larger changes in bryophyte communities. This hypothesis is open to testing via observational

472 and experimental studies of the effect of vascular plants on bryophytes communities under warming

473 or other environmental changes. Understanding temporal changes in one component of the

474 community may require more consideration of interactions with other components (Chesson, 2000;

475 HilleRisLambers, Adler, Harpole, Levine, \& Mayfield, 2012).

\section{$476 \quad$ Conclusion and conservation implications}

477 Overall, we found a significant temporal shift in the composition of both taxa in both parks but only 478 one significant change in $\alpha$-diversity. Our results are in accordance with recent meta-analyses and 479 syntheses showing that local diversity can remain unchanged (or increase or decrease with equal 480 likelihood) despite strong changes in composition (Blowes et al., 2019; Dornelas et al., 2014; Gotelli

481 et al., 2017; Magurran et al., 2018; Spaak et al., 2017; Vellend, Dornelas, et al., 2017). Finally, 482 regardless of whether one taxon is systematically more or less sensitive to environmental change 483 than another, our results suggest that one taxon (e.g., vascular plants) cannot be used as a surrogate 484 for others (e.g., bryophytes) in terms of predicting the nature and magnitude of responses to 485 environmental change (Bagella, 2014; Becker-Scarpitta et al., 2017; Outhwaite et al., n.d.). In the same 486 plots that experienced the same environmental changes, we found that communities of bryophytes 487 and vascular plants did not predictably change in the same ways (Bagella, 2014; Becker-Scarpitta et 488 al., 2017; Lalanne et al., 2008; Odland et al., 2014; Slack, 1977). Thus, to assess overall biodiversity 489 responses to global change data from different taxonomical groups and community properties need 490 to be synthesized. 


\section{Acknowledgements}

493 We would like to thank the field assistants who greatly contributed to the collection of data in the

494 field, the identification of species in the laboratory and the realization of the herbarium: Melissa

495 Paquette and Sara Gaignard. This work was made possible thanks to the support of park man- agers,

496 especially Camille-Antoine Ouimet (at Mont-Mégantic) and Daniel Sigouin (at Forillon). We also thank

497 Guillaume Blanchet, Michael Belluau and Willian Vieira for constructive discussion on this project.

498 The project was funds by the Natural Sciences and Engineering Research Council, Canada and field

499 mission were support by the Quebec Center for Biodiversity Sciences (QCBS).

\section{Authors' contribution}

502 ABS and MV conceived the ideas, design methodology, and wrote the manuscript collaboratively with

503 ABS as leader and DAL revising the manuscript; ABS and DAL collected and analyzed the data. All

504 authors contributed critically to the drafts and gave final approval for publication.

\section{$505 \quad$ Data availability}

506 All specimens identified at the species level were deposited in the Marie-Victorin herbarium

507 (Université de Montréal, Canada.) and all locations were entered into the GBIF database (GBIF -

508 https://www.gbif.org/). The dataset per se was deposit into the forestREplot database

509 (http://www.forestreplot.ugent.be/) under the reference: N_AM_005 for Mont-Mégantic and

$510 \quad$ N_AM_008 for Forillon.

\section{$512 \underline{\text { References }}$}

513 Anderson, M. J. (2001). A new method for non-parametric multivariate analysis of variance. Austral $514 \quad$ Ecology, 26(1), 32-46. doi: 10.1111/j.1442-9993.2001.tb00081.x

515 Anderson, M. J., Ellingsen, K. E., \& McArdle, B. H. (2006). Multivariate dispersion as a measure of beta 
diversity. Ecology Letters, 9(6), 683-693. doi: 10.1111/j.1461-0248.2006.00926.x

Augustine, D. J., \& Decalesta, D. (2003). Defining deer overabundance and threats to forest communities: From individual plants to landscape structure. Écoscience, 10(4), 472-486. doi: 10.1080/11956860.2003.11682795

Bagella, S. (2014). Does cross-taxon analysis show similarity in diversity patterns between vascular plants and bryophytes? Some answers from a literature review. Comptes Rendus Biologies, 337(4), 276-282. doi: 10.1016/j.crvi.2014.01.003

Baselga, A. (2012). The relationship between species replacement, dissimilarity derived from nestedness, and nestedness. Global Ecology and Biogeography, 21(12), 1223-1232. doi: 10.1111/j.1466-8238.2011.00756.x

Baselga, A., \& Leprieur, F. (2015). Comparing methods to separate components of beta diversity. Methods in Ecology and Evolution, 6(9), 1069-1079. doi: 10.1111/2041-210X.12388

Bates, D., Mächler, M., Bolker, B., \& Walker, S. (2015). Fitting Linear Mixed-Effects Models Using lme4. Journal of Statistical Software, 67(1), 1-48. doi: 10.18637/jss.v067.i01

Becker-Scarpitta, A., Bardat, J., Lalanne, A., \& Vellend, M. (2017). Long-term community change: bryophytes are more responsive than vascular plants to nitrogen deposition and warming. Journal of Vegetation Science, 28(6), 1220-1229. doi: 10.1111/jvs.12579

Becker-Scarpitta, A., Vissault, S., \& Vellend, M. (2019). Four decades of plant community change along a continental gradient of warming. Global Change Biology, 25(5), 1629-1641. doi: 10.1111/gcb.14568

Bergamini, A., Ungricht, S., \& Hofmann, H. (2009). An elevational shift of cryophilous bryophytes in the last century - an effect of climate warming? Diversity and Distributions, 15(5), 871-879. doi: 10.1111/j.1472-4642.2009.00595.x

Bertrand, R., Lenoir, J., Piedallu, C., Riofrío-Dillon, G., de Ruffray, P., Vidal, C., ... Gégout, J.-C. (2011). Changes in plant community composition lag behind climate warming in lowland forests. Nature, 479(7374), 517-520. doi: 10.1038/nature10548

Blowes, S. A., Supp, S. R., Antão, L. H., Bates, A., Bruelheide, H., Chase, J. M., ... Dornelas, M. (2019). The geography of biodiversity change in marine and terrestrial assemblages. Science, 366(6463), 339-345. doi: 10.1126/science.aaw1620

Braun-Blanquet, J., Roussine, N., \& Nègre, R. (1952). Les Groupements Végétaux de la France Méditerranéenne (CNRS; CNRS, Ed.). Montpellier: CNRS.

Bruun, H. H., Moen, J., Virtanen, R., Grytnes, J., Oksanen, L., \& Angerbjörn, A. (2006). Effects of altitude and topography on species richness of vascular plants, bryophytes and lichens in alpine communities. Journal of Vegetation Science, 17(1), 37-46. doi: 10.1111/j.16541103.2006.tb02421.x

Chen, I.-C., Hill, J. K., Ohlemuller, R., Roy, D. B., \& Thomas, C. D. (2011). Rapid Range Shifts of Species Associated with High Levels of Climate Warming. Science, 333(6045), 1024-1026. doi: 10.1126/science.1206432

Chesson, P. (2000). Mechanisms of maintenance of species diversity. Annual Review of Ecology and Systematics, 31(1), 343-366. doi: 10.1146/annurev.ecolsys.31.1.343

Chytrý, M., Tichý, L., Hennekens, S. M., \& Schaminée, J. H. J. (2014). Assessing vegetation change using vegetation-plot databases: a risky business. Applied Vegetation Science, 17(1), 32-41. doi: 10.1111/avsc. 12050 
559

560

561

562

563

564

565

566

567

568

569

570

571

572

573

574

575

576

577

578

579

580

581

582

583

584

585

586

587

588

589

590

591

592

593

594

595

596

597

598

599

600

Clavel, J., Julliard, R., \& Devictor, V. (2011). Worldwide decline of specialist species: toward a global functional homogenization? Frontiers in Ecology and the Environment, 9(4), 222-228. doi: $10.1890 / 080216$

Commission Joint International. (2014). Canada - United States, Air quality agreement - progress report. Retrieved from http://publications.gc.ca/collections/collection_2015/ec/En85-1-2014eng.pdf

Côté, S. D., Rooney, T. P., Tremblay, J.-P., Dussault, C., \& Waller, D. M. (2004). Ecological impacts of Deer overabundance. Annual Review of Ecology, Evolution, and Systematics, 35(1), 113-147. doi: 10.1146/annurev.ecolsys.35.021103.105725

De Cáceres, M., Legendre, P., \& Moretti, M. (2010). Improving indicator species analysis by combining groups of sites. Oikos, 119(10), 1674-1684. doi: 10.1111/j.1600-0706.2010.18334.x

de la Cretaz, A. L., \& Kelty, M. J. (2002). Development of tree regeneration in fern-dominated forest understories after reduction of Deer browsing. Restoration Ecology, 10(2), 416-426. doi: 10.1046/j.1526-100X.2002.02037.x

Delgado, V., \& Ederra, A. (2013). Long-term changes (1982-2010) in the bryodiversity of Spanish beech forests assessed by means of Ellenberg indicator values of temperature, nitrogen, light and pH. Biological Conservation, 157, 99-107. doi: 10.1016/j.biocon.2012.06.022

Dornelas, M., Gotelli, N. J., McGill, B., Shimadzu, H., Moyes, F., Sievers, C., \& Magurran, A. E. (2014). Assemblage time series reveal biodiversity change but not systematic loss. Science, 344(6181), 296-299. doi: 10.1126/science.1248484

Faubert, J (2012) Flore des bryophytes du Québec-Labrador, Vol. 1, Anthocérotes et hépatiques. Société québécoise de bryologie, Saint-Valérien, Québec, 356 pp.

Faubert, J (2013) Flore des bryophytes du Québec-Labrador, Vol. 2, Mousses, première partie. Société québécoise de bryologie, Saint-Valérien, Québec, 402 pp.

Faubert, J (2014) Flore des bryophytes du Québec-Labrador, Vol. 3, Mousses, seconde partie. Société québécoise de bryologie, Saint-Valérien, Québec, 456 pp.

Fenton, N. J., \& Bergeron, Y. (2013). Stochastic processes dominate during boreal bryophyte community assembly. Ecology, 94(9), 1993-2006. doi: 10.1890/12-1944.1

Frerker, K., Sabo, A., \& Waller, D. (2014). Long-term regional shifts in plant community composition are largely explained by local deer impact experiments. PLOS ONE, 9(12), e115843. doi: 10.1371/journal.pone.0115843

Geffert, J. L., Frahm, J.-P., Barthlott, W., \& Mutke, J. (2013). Global moss diversity: spatial and taxonomic patterns of species richness. Journal of Bryology, 35(1), 1-11. doi: 10.1179/1743282012Y.0000000038

Gignac, L. D. (2001). Bryophytes as indicators of climate change. The Bryologist, 104(3), 410-420.

Glime, J. M. (2007). Bryophyte Ecology. Volume 1. Physiological Ecology. Retrieved from http://www.bryoecol.mtu.edu/

Glime, J. M. (2013). Life cycles : surviving change, Chap 2.2. In Bryophyte Ecology. Vol. 1 Physiology and Ecology. Retrieved from www.bryoecol.mtu.edu

Gotelli, N. J., Shimadzu, H., Dornelas, M., McGill, B., Moyes, F., \& Magurran, A. E. (2017). Communitylevel regulation of temporal trends in biodiversity. Science Advances, 3(7), e1700315. doi: 10.1126/sciadv.1700315 
601

602

603

604

605

606

607

608

609

610

611

612

613

614

615

616

617

618

619

620

621

622

623

624

625

626

627

628

629

630

631

632

633

634

635

636

637

638

639

640

641

642

643

Grytnes, J. A., Heegaard, E., \& Ihlen, P. G. (2006). Species richness of vascular plants, bryophytes, and lichens along an altitudinal gradient in western Norway. Acta Oecologica, 29(3), 241-246. doi: 10.1016/j.actao.2005.10.007

Harrison, S. (2020). Plant community diversity will decline more than increase under climatic warming. Philosophical Transactions of the Royal Society B: Biological Sciences, 375(1794), 20190106. doi: 10.1098/rstb.2019.0106

He, X., He, K. S., \& Hyvönen, J. (2016). Will bryophytes survive in a warming world? Perspectives in Plant Ecology, Evolution and Systematics, 19, 49-60. doi: 10.1016/j.ppees.2016.02.005

Hédl, R., Bernhardt-Römermann, M., Grytnes, J.-A., Jurasinski, G., \& Ewald, J. (2017). Resurvey of historical vegetation plots: a tool for understanding long-term dynamics of plant communities. Applied Vegetation Science, 20(2), 161-163. doi: 10.1111/avsc.12307

Hember, R. A. (2018). Spatially and temporally continuous estimates of annual total nitrogen deposition over North America, 1860-2013. Data in Brief, 17, 134-140. doi: 10.1016/j.dib.2017.12.052

HilleRisLambers, J., Adler, P. B., Harpole, W. S., Levine, J. M., \& Mayfield, M. M. (2012). Rethinking community assembly through the lens of coexistence theory. Annual Review of Ecology, Evolution, and Systematics, 43(1), 227-248. doi: 10.1146/annurev-ecolsys-110411-160411

Hudson, J. M. G., \& Henry, G. H. R. (2010). High Arctic plant community resists 15 years of experimental warming. Journal of Ecology, 98(98), 1035-1041. doi: 10.1111/j.13652745.2010.01690.x

Jägerbrand, A. K., Kudo, G., Alatalo, J. M., \& Molau, U. (2012). Effects of neighboring vascular plants on the abundance of bryophytes in different vegetation types. Polar Science, 6(2), 200-208. doi: 10.1016/j.polar.2012.02.002

Jiang, Y., Liu, X., Song, S., Yu, Z., \& Shao, X. (2015). Diversity and distribution of ground bryophytes in broadleaved forests in Mabian Dafengding National Nature Reserve, Sichuan, China. Acta Ecologica Sinica, 35(2), 13-19. doi: 10.1016/j.chnaes.2015.03.002

Kaufmann, S., Hauck, M., \& Leuschner, C. (2017). Comparing the plant diversity of paired beech primeval and production forests: Management reduces cryptogam, but not vascular plant species richness. Forest Ecology and Management, 400, 58-67. doi: 10.1016/j.foreco.2017.05.043

Kraft, N. J. B., Comita, L. S., Chase, J. M., Sanders, N. J., Swenson, N. G., Crist, T. O., ... Myers, J. a. (2011). Disentangling the drivers of diversity along latitudinal and elevational gradients. Science, 333(6050), 1755-1758. doi: 10.1126/science.1208584

Lalanne, A., Bardat, J., Lalanne-Amara, F., Gautrot, T., \& Ponge, J.-F. (2008). Opposite responses of vascular plant and moss communities to changes in humus form, as expressed by the Humus Index. Journal of Vegetation Science, 19(5), 645-652. doi: 10.3170/2007-8-18431

Lee, T. D., \& La Roi, G. H. (1979). Bryophyte and understory vascular plant beta diversity in relation to moisture and elevation gradients. Vegetatio, 40(1), 29-38.

Lenoir, J., Gegout, J. C., Marquet, P. A., de Ruffray, P., \& Brisse, H. (2008). A significant upward shift in plant species optimum elevation during the 20th century. Science, 320(5884), 1768-1771. doi: 10.1126/science.1156831

Lindo, Z., \& Gonzalez, A. (2010). The bryosphere: An integral and influential component of the Earth's biosphere. Ecosystems, 13(4), 612-627. doi: 10.1007/s10021-010-9336-3 
644

645

646

647

648

649

650

651

652

653

654

655

656

657

658

659

660

661

662

663

664

665

666

667

668

669

670

671

672

673

674

675

676

677

678

679

680

681

682

683

684

685

686

Magurran, A. E., Deacon, A. E., Moyes, F., Shimadzu, H., Dornelas, M., Phillip, D. A. T., \& Ramnarine, I. W. (2018). Divergent biodiversity change within ecosystems. Proceedings of the National Academy of Sciences, 115(8), 1843-1847. doi: 10.1073/pnas.1712594115

Majcen, Z. (1981). Les forets du parc national Forillon, Gaspésie, Québec, étude phytosociologique. Université de Laval.

Marcotte, G., \& Grandtner, M. (1974). Étude écologique de la végétsation forestière du Mont Mégantic. Université de Laval.

Marie-Victorin, F. (1997). Flore laurentienne. Troisième édition mise à jour et annotée par L. Brouillet, SG Hay, I. Goulet, M. Blondeau, J. Cayouette et J. Labrecque. In Imprimerie de la Salle. Montréal, Canada: Les Presses de l’Université de Montréal.

Mateo, R. G., Broennimann, O., Normand, S., Petitpierre, B., Araújo, M. B., Svenning, J.-C., ... Vanderpoorten, A. (2016). The mossy north: an inverse latitudinal diversity gradient in European bryophytes. Scientific Reports, 6(1), 25546. doi: 10.1038/srep25546

McCune, J. L., \& Vellend, M. (2013). Gains in native species promote biotic homogenization over four decades in a human-dominated landscape. Journal of Ecology, 101(6), 1542-1551. doi: 10.1111/1365-2745.12156

McGill, B. J., Dornelas, M., Gotelli, N. J., \& Magurran, A. E. (2015). Fifteen forms of biodiversity trend in the Anthropocene. Trends in Ecology \& Evolution, 30(2), 104-113. doi: 10.1016/j.tree.2014.11.006

Möls, T., Vellak, K., Vellak, A., \& Ingerpuu, N. (2013). Global gradients in moss and vascular plant diversity. Biodiversity and Conservation, 22(6-7), 1537-1551. doi: 10.1007/s10531-013-04926

Mouquet, N., \& Loreau, M. (2003). Community patterns in source-sink metacommunities. The American Naturalist, 162(5), 544-557. doi: 10.1086/378857

Nascimbene, J., \& Spitale, D. (2017). Patterns of beta-diversity along elevational gradients inform epiphyte conservation in alpine forests under a climate change scenario. Biological Conservation, 216, 26-32. doi: 10.1016/j.biocon.2017.09.021

Odland, A., Reinhardt, S., \& Pedersen, A. (2014). Differences in richness of vascular plants, mosses, and liverworts in southern Norwegian alpine vegetation. Plant Ecology \& Diversity, 00(00), 111. doi: 10.1080/17550874.2013.862751

Outhwaite, C. L., Gregory, R. D., Chandler, R. E., Collen, B., \& Isaac, N. J. B. (2020). Complex long-term biodiversity change among invertebrates, bryophytes and lichens. Nature Ecology \& Evolution, 4(3), 384-392. doi: 10.1038/s41559-020-1111-z

Patiño, J., \& Vanderpoorten, A. (2018). Bryophyte Biogeography. Critical Reviews in Plant Sciences, 37(2-3), 175-209. doi: 10.1080/07352689.2018.1482444

Pauli, H., Gottfried, M., Dullinger, S., Abdaladze, O., Akhalkatsi, M., Alonso, J. L. B., ... Grabherr, G. (2012). Recent Plant Diversity Changes on Europe's Mountain Summits. Science, 336(6079), 353-355. doi: 10.1126/science.1219033

Pharo, E. J., \& Vitt, D. H. (2000). Local variation in bryophyte and macro-lichen cover and density in diversity in montane forests of western Canada. The Bryologist, 103(3), 455-466. doi: 10.1639/0007-2745(2000)103[0455:LVIBAM]2.0.CO;2

Raabe, S., Müller, J., Manthey, M., Dürhammer, O., Teuber, U., Göttlein, A., ... Bässler, C. (2010). Drivers of bryophyte diversity allow implications for forest management with a focus on 
climate change. Forest Ecology and Management, 260(11), 1956-1964. doi:

Rooney, T. P. (2009). High white-tailed deer densities benefit graminoids and contribute to biotic homogenization of forest ground-layer vegetation. Plant Ecology, 202(1), 103-111. doi: 10.1007/s11258-008-9489-8

Rumpf, S. B., Hülber, K., Klonner, G., Moser, D., Schütz, M., Wessely, J., ... Dullinger, S. (2018). Range dynamics of mountain plants decrease with elevation. Proceedings of the National Academy of Sciences, 115(8), 1848-1853. doi: 10.1073/pnas.1713936115

Rydin, H. (2008). Population and community ecology of bryophytes. In Bryophyte Biology (pp. 393444). doi: DOI: 10.1017/CB09780511754807.011

Savage, J., \& Vellend, M. (2015). Elevational shifts, biotic homogenization and time lags in vegetation change during 40 years of climate warming. Ecography, 38(6), 546-555. doi: 10.1111/ecog.01131

Slack, N. G. (1977). Species diversity and community structure in bryophytes: New York State studies. New York State Museum, The University of the State of New York.

Socolar, J., Gilroy, J., Kunin, W., \& Edwards, D. (2016). How should beta-diversity inform biodiversity conservation? Trends in Ecology \& Evolution, 31(1), 67-80. doi: http://dx.doi.org/10.1016/j.tree.2015.11.005

Spaak, J. W., Baert, J. M., Baird, D. J., Eisenhauer, N., Maltby, L., Pomati, F., ... De Laender, F. (2017). Shifts of community composition and population density substantially affect ecosystem function despite invariant richness. Ecology Letters, 20(10), 1315-1324. doi: $10.1111 /$ ele.12828

Stockli, V., Wipf, S., Nilsson, C., \& Rixen, C. (2012). Using historical plant surveys to track biodiversity on mountain summits. Plant Ecology and Diversity, 4(4), 415-425. doi: 10.1080/17550874.2011.651504

Tuba, Z., Slack, N. G., \& Stark, L. R. (2011). Bryophyte ecology and climate change. Cambridge: Cambridge University Press.

Turetsky, M. R. (2003). The role of Bryophytes in carbon and nitrogen cycling. The Bryologist, 106(3), 395-409. doi: 10.1639/05

UQCN. (2005). Rapport de synthèse - Parc National de Forillon. Importance et impacts des pressions périphériques sur le maintien de l'intégrité écologique des aires protégées au Québec. Retrieved from http://www.naturequebec.org/fichiers/Aires_protegees/Rapport_projet_PAPE_PDFMars/Aire s_protegees/Forillon.pdf

Urban, M. C. (2015). Accelerating extinction risk from climate change. Science, 348(6234), 571-573. doi: $10.1126 /$ science.aaa4984

Vanneste, T., Michelsen, O., Graae, B. J., Kyrkjeeide, M. O., Hassel, K., Lindmo, S., \& Frenne, P. De. (2017). Impact of climate change on alpine vegetation of mountain summits in Norway. Ecological Research, 32, 579-593. doi: 10.1007/s11284-017-1472-1

Vellend, M., Baeten, L., Becker-Scarpitta, A., Boucher-Lalonde, V., McCune, J. L., Messier, J., ... Sax, D. F. (2017). Plant biodiversity change across scales during the anthropocene. Annual Review of Plant Biology, 68(1), 563-586. doi: 10.1146/annurev-arplant-042916-040949

Vellend, M., Brown, C. D., Kharouba, H. M., McCune, J. L., \& Myers-Smith, I. H. (2013). Historical 
ecology: Using unconventional data sources to test for effects of global environmental change. American Journal of Botany, 100(7), 1294-1305. doi: 10.3732/ajb.1200503

Vellend, M., Dornelas, M., Baeten, L., Beauséjour, R., Brown, C. D., De Frenne, P., ... Sievers, C. (2017). Estimates of local biodiversity change over time stand up to scrutiny. Ecology, 98(2), 583-590. doi: $10.1002 /$ ecy.1660

Verheyen, K., De Frenne, P., Baeten, L., Waller, D. M., Hédl, R., Perring, M. P., ... BernhardtRömermann, M. (2017). Combining biodiversity resurveys across regions to advance global change research. BioScience, 67(1), 73-83. doi: 10.1093/biosci/biw150

Virtanen, R., Eskelinen, A., \& Harrison, S. (2017). Comparing the responses of bryophytes and shortstatured vascular plants to climate shifts and eutrophication. Functional Ecology, 31(4), 946954. doi: 10.1111/1365-2435.12788

Vittoz, P., Camenisch, M., Mayor, R., Miserere, L., Vust, M., \& Theurillat, J.-P. (2010). Subalpine-nival gradient of species richness for vascular plants, bryophytes and lichens in the Swiss Inner Alps. Botanica Helvetica, 120(2), 139-149. doi: 10.1007/s00035-010-0079-8

Yagouti, A., Boulet, G., Vincent, L., Vescovi, L., \& Mekis, É. (2008). Observed changes in daily temperature and precipitation indices for southern Québec, 1960-2005. Atmosphere-Ocean, 46(2), 243-256. doi: 10.3137/ao.460204

\section{Supplementary Materials}

$749 \quad-\quad$ Appendix S1 - Taxonomic standardization of bryophytes species between surveys

$750 \quad$ - Appendix S2 - Mean species elevation and sum of occurrences for bryophytes for original and

751 recent survey in Forillon and Mont-Mégantic 